\title{
The Genetics of Keratoconus: A Review
}

\author{
Joshua Wheeler ${ }^{1}$, Michael A. Hauser ${ }^{1,2}$, Natalie A. Afshari ${ }^{2}$, R. Rand Allingham ${ }^{2}$, and Yutao \\ $\mathrm{Liu}^{1, *}$ \\ ${ }^{1}$ Center for Human Genetics, Department of Medicine, Duke University Medical Center, Durham, \\ NC, USA 27710 \\ ${ }^{2}$ Department of Ophthalmology, Duke University Medical Center, Durham, NC, USA 27710
}

\begin{abstract}
Keratoconus is the most common ectatic disorder of the corneal. Genetic and environmental factors may contribute to its pathogenesis. The focus of this article is to summarize current research into the complex genetics of keratoconus. We discuss the evidence of genetic etiology including family-based linkage studies, twin studies, genetic mutations, and genome-wide association studies. The genes implicated potentially include VSX1, miR-184, DOCK , SOD1, $R A B 3 G A P 1$, and $H G F$. Besides the coding mutations, we also highlight the potential contribution of DNA copy number variants in the pathogenesis of keratoconus. Finally, we present future directions for genetic research in the understanding of the complex genetics of keratoconus and its clinical significance. As new functional, candidate genes for keratoconus are being discovered at a rapid pace, the molecular genetic mechanisms underlying keratoconus pathogenesis will advance our understanding of keratoconus and promote the development of a novel therapy.
\end{abstract}

\section{Keywords}

Keratoconus; Genetics; VSX1; miR-184; DOCK9; GWAS; Linkage; Association; Cornea

\section{Introduction}

\begin{abstract}
Keratoconus is the most common primary corneal ectatic disease [1,2]. Its name is derived from the Greek words kerato meaning cornea and conus meaning cone. Keratoconus is characterized by the non-inflammatory, localized paraxial stromal thinning of the cornea which ofen results in bilateral and asymmetrical corneal distortion and anterior corneal protrusion [3]. Patients with corneal protrusion ofen develop high myopia and irregular astigmatism resulting in significant impairment of visual acuity [1]. Keratoconus usually appears during puberty or the second decade of the life and normally progresses for the following two decades until it stabilizes [4]. In severe cases, corneal scarring from decomposition and corneal edema further contribute to vision loss. The clinical symptoms of keratoconus vary with disease severity. In moderate and advanced cases of keratoconus, a very common sign is Fleischer's ring around the cone base due to an accumulation of iron deposits [2]. Another characteristic is Vogt's striae (Figure 1), fine vertical lines due to compression of Descemet's membrane [2]. Eventually most of the patients develop Munson's sign [5] (Figure 2), bulging of the lower lid on downgaze caused by corneal protrusion. Patients with severe keratoconus were noticed to have corneal hydrops, acute
\end{abstract}

Copyright: (C) 2011 Wheeler J, et al.

*Corresponding author: 905 S LaSalle Street, DUMC BOX 3445, Durham, NC, USA 27710, Tel: +1-919-684-7090; Fax: +1-919-684-0918; yutao.liu@duke.edu. 
stromal edema leading to stromal scarring due to breaks in Descemet's membrane [1] (Figure 3). Corneal topography is the most sensitive approach to detect early symptoms of keratoconus by identifying subtle corneal steepening (Figure 4). Keratoconus is a major indication for corneal transplantation in the Western world [6]. Despite extensive research, the exact cause of keratoconus remains unknown in the majority of patients. The aim of this article is to review the evidence for the complex genetics of keratoconus, to evaluate the currently identified genes/loci and candidate gene/loci, and to highlight current research methodologies which may be used to further elucidate the pathogenesis of keratoconus.

\section{Epidemiology of Keratoconus}

Keratoconus is the most common corneal ectatic disorder. It affects both genders and all ethnicities. The reported prevalence and incidence of keratoconus remains largely variable due to different clinical definitions and diagnostic criteria utilized between studies and populations. By best estimates, the incidence of keratoconus in the European Caucasian population is reported to be between 5 and 23 with a mean prevalence of 54 per 100,000 $[2,7]$. Based on a 48-year epidemiological study conducted in the United States, keratoconus reportedly affects approximately one person in 2,000 with a total mean incidence of two new cases per 100,000 per year [8].

Although the source of case reports may be biased and affected by disproportional cornea transplants in keratoconus patients, increased incidence of keratoconus has been described in a number of populations. It was reported to exhibit a higher incidence in Asians compared to Caucasians, a ratio of 7.5:1 respectively [9]. In comparison to incidence rates in Caucasians, similar rates of keratoconus incidence (1.3 patients per 100,000 residents per year) and prevalence (86 patients per 100,000) were reported in a Danish population [10]. In an Israeli epidemiological study, keratoconus prevalence was reported to be as high as $2.34 \%$ [11]. Moreover, increased incidence of keratoconus was reported in an Indian rural population and a Saudi Arabian population with 2.3 and 20 cases per 100,000 respectively [12,13]. In these three populations, the influence of consanguinity and a positive family history of keratoconus were suggested to have contributed to the increased incidence. Although the majority of patients present to the clinic as a sporadic form of the disease, a large number of familial cases of keratoconus have been reported. Many studies have shown that 11-14\% of unaffected relatives of keratoconus patients who initially present to the clinic as sporadic cases are ofen reclassified as familial keratoconus if complete slit-lamp examination, refraction, and corneal topography were performed [14]. It is becoming increasingly clear in most familial cases of keratoconus that the disease is inherited as a Mendelian trait, where specific genetic mutations cause keratoconus.

\section{Chromosomal Loci for Keratoconus}

A genetic predisposition to keratoconus is well documented with increased incidence in some familial groups and numerous reports of concordance between monozygotic twins [14-19]. Familial keratoconus cases are common with reports of incomplete penetrance in first and second degree family members of affected individuals. Approximately $6-23.5 \%$ of patients with keratoconus have a positive family history [14,20,21]. Similar to other ocular genetic disorders, studies have indicated that relatives of keratoconus patients have an elevated risk (15-67 times higher risk of developing keratoconus) compared to those with unaffected relatives [1,21]. The majority of familial keratoconus is inherited through an autosomal dominant pattern [2,22]. Other models of inheritance such as autosomal recessive pattern have been suggested especially in populations of high consanguinity [22-24].

Family-based linkage studies have provided invaluable insight into identifying candidate genetic loci that may harbor pathogenic mutations $[2,21,25]$. Linkage analyses with 
keratoconus have identified at least 17 genomic loci from 12 different studies (Table 1), suggesting genetic heterogeneity in keratoconus epidemiology $[2,26]$. This means that keratoconus could be caused by mutations in a number of different genes in different families [2,21]. While most of these loci have not been independently replicated, the 5q21.2 locus has been independently replicated in two different studies [27,28]. A third study by Li et al. [29] in 2006 identified a region on 5q23.2, overlapping with the replicated region $5 \mathrm{q} 21.2$. The overlap between these three independent linkage analyses indicates the possibility of the same locus for keratoconus. In addition, the linkage locus in 5q32-33 overlaps between two studies, one from Li et al. [29] in 2006 and Bisceglia et al. [27] in 2009 although both studies provided suggestive linkage. An additional linkage locus in $14 q 11.2$ was also suggested by these two studies [27, 29]. The suggestive linkage region $16 \mathrm{q} 23$ reported by Bisceglia et al. [27] is very close to the region 16q22.3-q23.1 identified by Tyynismaa et al. [30]. In summary, these three linkage regions independently identified in at least two different familial datasets provide further evidence of association with keratoconus development. Despite the extensive genetic research in keratoconus over the past decades, only few genes have been reported: VSX1 (visual system homeobox 1), miR-184, and DOCK9 (dedicator of cytokinese 9).

\section{Reported Keratoconus Genes}

\section{VSX1 (Visual System Homeobox 1)}

VSX1 (OMIM 605020) is located on chromosome 20p11-q11 [31,32], a linkage locus known for a corneal dystrophy called posterior polymorphous dystrophy (PPCD) [33]. PPCD has been associated with keratoconus in several reports [34-39]. It was first reported in 2002 that $V S X 1$ mutations cause keratoconus and posterior polymorphous dystrophy [40].Two mutations in $V S X 1$ (R166W and L159M) were reported to be associated with keratoconus. $V S X 1$ is a member of the paired-like homeodomain transcription factors. This gene encodes a pair-like homeodomian protein which binds to the core of the locus control region of the red and green visual pigment gene cluster and may regulate expression of the cone opsin genes during embryonic development [41, 42]. It is expressed in several ocular tissues including the nuclear layer of the retina, and embryonic craniofacial tissue $[31,32,40]$. The expression of $V S X 1$ in human or mouse cornea is still up to debate since many studies did not confirm the expression in cornea [40,41,43]. Mouse models with the loss of VSX1 function did not reveal cornea-related phenotypes [42].

Since the initial report in 2002, mutations in VSX1 have been demonstrated to be associated with keratoconus and other corneal dystrophies (Table 2) [44-52]. However, many studies did not identify any potential $V S X 1$ mutations in keratoconus patients [22,24,53-60]. It remains unclear whether and how mutations in $V S X 1$ contribute to the pathogenesis of keratoconus $[2,9,61]$. It is suggested that mutations within $V S X 1$ only affect a small number of keratoconus patients. This is consistent with the concept of genetic heterogeneity in keratoconus.

$\operatorname{miR}-184$

miR-184 is a microRNA. microRNAs (miRNAs) are small regulatory strands of RNA with 19-25 nucleotides in length. miRNAs bind to complementary sequences mostly in the $3^{\prime}$ untranslated region (UTR) of mRNA of target genes and lead to mRNA degradation or translational suppression. Recently, a mutation altering the miR-184 seed region was reported in a family with keratoconus and early-onset anterior polar cataract [62]. This genomic region chr15q22-q25 was previously mapped as a keratoconus linkage locus $[20,63]$. This $5 \mathrm{Mb}$ linkage region was enriched in affected and unaffected family members using a custom sequence capture array from NimbleGen. The enriched DNA was sequenced 
using second generation DNA sequencing (Genome Analyzer II from Illumina), identifying a mutation $(\mathrm{r} .57 \mathrm{c}>\mathrm{u})$ within $m i R-184$ [62]. $m i R-184$ has been reported to be abundantly expressed in the cornea and lens $[64,65]$. The authors hypothesized that miR-184 with the $\mathrm{r}$. $57 \mathrm{c}>\mathrm{u}$ mutation fails to compete with another miRNA - miR-205 for overlapping target sites on the $3^{\prime}$ UTR of two target genes, INPPL1 (inositol polyphosphate phosphatase-like 1) and ITGB4 (integrin beta 4) while these two target genes are involved in corneal healing afer injury as the principal component of corneal basal epithelial hemidesmosomes [62]. The finding of mutations in the seed region of $m i R-184$ suggests that regulatory variants may directly impact transcriptional activity of key genes in corneal development and maintenance. It will be necessary to replicate this original finding in other studies of keratoconus.

\section{DOCK9 (Dedicator of Cytokinesis 9)}

DOCK9 (Dedicator of cytokinesis 9) (OMIM 607325) encodes a member of the DOCK protein family that possesses GTP/GDP exchange factor activity and specifically activates G-protein CDC42 [66]. DOCK9 is a strong candidate gene for keratoconus. Mutations in $D O C K 9$ were recently reported through sequencing candidate genes in a previously identified linkage locus, 13q32 [57]. This locus was first identified by Gajecka $M$ et al. [57] in a large Ecuadorian family, and was reported to segregate under an autosomal dominant model [67]. A mutation screening of eight candidate genes within the 13q32 locus identified $100 \%$ segregation of one non-synonymous mutation and three different sequence variants in the DOCK 9 gene and two additional genes, IPO5 (importin 5, OMIM 602008) and STK24 (serine/threonine kinase 24, OMIM 604984) [67]. All these three genes are expressed in the human cornea [67]. Based on the bioinformatics analyses with two available programs PolyPhen (polymorphism phenotyping) and SIFT (sorting intolerant from tolerant) $[68,69]$, the authors suggested that the most functionally significant of these three candidate genes is DOCK 9 . However, functional work of the identified non-synonymous mutation (Gln754His) and additional keratoconus families with mutations in the DOCK9 gene will be necessary to demonstrate the true pathogenic potential of this gene in relation to keratoconus [67].

\section{Candidate Genes Associated with Keratoconus SOD1 (superoxide dismutase 1)}

Several reports have suggested the potential contribution of $S O D 1$ (superoxide dismutase 1) in keratoconus [70]. SOD1 (OMIM 147450) maps to the 20p11.2 and encodesa major cytoplasmic antioxidant enzyme that metabolizes superoxide radicals and provides a defense against oxygen toxicity [71]. Mutations in the SOD1 gene have been implicated in familial amyotrophic lateral sclerosis (ALS) [71,72]. No keratoconus phenotype was reported in ALS patients. To date, it is widely accepted that oxidative stress plays a critical role in the progression of keratoconus [2,22]. Numerous reports have shown an accumulation of cytotoxic byproducts, mitochondrial DNA damage, and high levels of oxidative stress in keratoconus corneas [73-76]. SOD1 was selected as a candidate gene and was examined in many studies. However, no mutations were found in keratoconus patients $[50,52,57,59,70,77]$. It remains unclear whether $S O D 1$ plays a role in the pathogenesis of keratoconus.

\section{Genome-Wide Association Studies}

Genome-wide association studies (GWAS) assay several hundred thousand to over a million single nucleotide polymorphisms (SNPs) in thousands of individuals using high throughput DNA genotyping technology [78]. GWAS has been shown to be a powerful tool to investigate the genetic etiology of many complex traits and diseases, including Fuchs' 
corneal dystrophies (FECD) and central corneal thickness [79-84]. Li and colleagues recently performed a GWAS with keratoconus in the Caucasian population of 222 patients and 3324 controls using Illumina 370k beadchips and no variants reached genome-wide significance (p-value $5 \times 10^{-8}$ ) [85]. The authors then selected a set of 4905 SNPs with pvalue $<10^{-4}$ in the discovery dataset for replication in two datasets, one with 304 cases and 518 controls and another with 70 multiplex families of 307 individuals. The meta-analysis of these selected SNPs did not identify any SNP with genome-wide significant association. However, the most significant association (p-value $1.6 \times 10^{-7}$ ) was with SNP rs 4954218 , located near the $R A B 3 G A P 1$ (RAB3 GTPase activating protein subunit 1 (catalytic)) gene on chromosome $2 \mathrm{q} 21.3$ [85]. Interestingly, mutations in the RAB3GAP1 gene are reportedly associated with Warburg Micro Syndrome, a rare, autosomal recessive syndrome characterized by ocular and neurodevelopmental abnormalities, especially microphthalmos, microcornea, congenital cataracts and optic atrophy [86,87].

A second GWAS in keratoconus was reported by Burdon and colleagues in Australia using pooled DNA in 97 keratoconus patients and 216 controls [88]. Although no variants reached genome-wide significance, the most significant association was with SNP rs1014091, located upstream of the $H G F$ (hepatocyte growth factor) gene. Further genotyping additional tagging SNPs for the HGF gene identified another SNP rs3735520 with significant association ( $\mathrm{p}$-value $9.9 \times 10^{-7}$ ). This SNP was also found to be associated with serum HGF level in normal individuals (p-value 0.036). Interestingly, the $H G F$ gene has been associated with refractive error in several populations including Han Chinese and Caucasians [89-91]. The association of $H G F$ with keratoconus suggests the potential involvement of inflammatory pathway [88].

\section{DNA Copy Number Variation}

In addition to sequence variants, DNA structural variants, or copy number variants (CNV) have been shown to play important roles in human diseases, including many ocular disorders $[25,92,93]$. The role of CNV in keratoconus has been explored in two studies. First, AbuAmero and colleagues investigated DNA copy number alteration in 20 sporadic keratoconus patients and 10 ethnically-matched health controls from Saudi Arabia using a genome-wide CGH array (comparative genomic hybridization) containing over 244,000 probes from Agilent [94]. This study did not identify genomic deletions or duplications specific for keratoconus. However, this finding should be interpreted with caution due to the relatively small sample size and low density of the probes. Second, Rosenfeld and colleagues identified DNA duplications and deletions of chromosome 5q31.1-q35.3 in a family with autosomal dominant keratoconus [95]. This genomic region on chr5 has been shown to be linked with keratoconus. The 5q31 region has also been implicated in granular, lattice and Reis Bucklers corneal dystrophies due to mutations in the TGF beta 1 gene (TGFBI) [96]. However, the copy number alterations in this region need to be replicated in additional datasetswith keratoconus patients. We expect more CNV studies will be reported with keratoconus.

\section{Related Ocular and Systemic Disorders}

Although the majority of keratoconus patients occur as an isolated disorder, keratoconus has been reported to be related with at least a dozen other ocular, syndromic, and systemic disorders [1-3], which include Marfan's syndrome, mitral valve prolapse, collagen vascular disease, pigmentary retinopathy, Leber congenital amaurosis, and Down Syndrome [2, 3]. Studies have reported that approximately 0.5 to $15 \%$ of patients with Down Syndrome manifest signs of keratoconus [2]. This increased incidence has been suggested to result in a 10 to 300 fold higher prevalence of keratoconus amongst patients with Down syndrome 
[2,97]. It has also been reported that approximately $35 \%$ of patients with Leber congenital amaurosis, a clinically heterogeneous group of childhood retinal degenerations inherited in an autosomal recessive manner, also suffer from keratoconus [98]. Of note, gene mutations in Aryl-hydrocarbon-interacting protein-like 1 (AIPL1) and Crumbs homolog 1 (CRBI) in patients with Leber congential amaurosis have been suggested to contribute keratoconus susceptibility [99-103]. Keratoconus and Leber congenital amaurosis concordance could likely be explained by the possibility for polygenic or multifactorial inheritance resulting in direct genetic alterations that affect both the retina and cornea. Since mutations in genes that affect retinal development have been well established for Leber congential amaurosis, it may suggest that a common ocular developmental genetic modifier could contribute to disease susceptibility for patients with keratoconus. Moreover, since keratoconus onset and severity is reported to be more advanced in patients with Leber congenital amurosis, a common genetic modifier could contribute to the rapid disease pathogenesis due to adverse corneal development. Associations between keratoconus and connective tissue disorders have also been reported including: osteogenesis imperfecta, GAPO syndrome, type IV Ehlers-Danlos syndrome, and mitral valve prolapse [104-107]. Interestingly, an association study between mitral valve prolapse, hypermobility, and keratoconus failed to detect a statistically significant difference in the prevalence of these disorders in keratoconus patients and controls [108]. In summary, the potential contribution of the associated disorders with keratoconus provides a further illustration of the genetic heterogeneity in keratoconus pathogenesis.

In addition, environmental factors have also been reported to potentially contribute to keratoconus. These factors include contact lens wear, chronic eye rubbing, magnesium deficiency, and atopy of the eye [1-3]. Notably, a growing body of evidence supports a potential association between atopy and keratoconus [109-114]. . Pathologically, keratoconus patients with atopy have been shown to present with corneal topographic and pachymetric characteristics different than those keratoconus patients without atopy [115]. It was speculated that atopy-induced itching might result in increased eye rubbing and contribute to keratoconus [111]. Supporting this hypothesis, in a multivariate analysis, Bawazeer and colleagues demonstrated a significant association in a case-control study between atopy, keratoconus, and eye rubbing [116]. More studies will be necessary to examine the interaction between the genetic and environmental factors and its contribution to keratoconus pathogenesis.

\section{Future Direction in Genetic Studies of Keratoconus}

Recent genome technology development has enabled novel and high throughput genetic approaches to study both Mendelian and complex disorders. Among these approaches, whole exome or genome sequencing will be very powerful to identify the causal mutations in multiplex families with keratoconus [117-119]. The existing linkage data on these families will be tremendously useful in the interpretation of exome sequencing data. We expect to see more publications using this approach to study keratoconus in the near future.

Another approach is to perform genome-wide association studies in a large number of keratoconus cases and controls using high density SNP arrays. This approach has been shown to be very promising in keratoconus $[85,88]$. Since GWAS studies need thousands of cases and controls, different laboratories will need to collaborate and combine each available dataset in order to identify genome-wide significant associations, which will help identify new genes involved in keratoconus pathogenesis. The available genome-wide genotype data will make it possible to study any potential gene-environment interactions. 


\section{Conclusion}

Keratoconus is the most common ectatic disorder of cornea. It usually develops in the second decade of the life around puberty time and progress in the next two decades. It affects both genders and all ethnic groups. Genetics has been shown to play an important role in its pathogenesis through twin studies, family-based linkage studies, and genetic association studies. However, despite the extensive research in the past decades, the genetic etiology of keratoconus still remains unclear. Keratoconus is associated with many ocular or systematic disorders. Newly developed genetic technologies including whole-exome or genome sequencing and GWAS will significantly advance the genetic research of keratoconus, which will improve our understanding of the genetic etiology of keratoconus, thus leading to future development of improved diagnostics and targeted therapeutics.

\section{References}

1. Rabinowitz YS. Keratoconus. Surv Ophthalmol. 1998; 42:297-319. [PubMed: 9493273]

2. Romero-Jimenez M, Santodomingo-Rubido J, Wolffsohn JS. Keratoconus: a review. Cont Lens Anterior Eye. 2010; 33:157-166. [PubMed: 20537579]

3. Krachmer JH, Feder RS, Belin MW. Keratoconus and related noninflammatory corneal thinning disorders. Surv Ophthalmol. 1984; 28:293-322. [PubMed: 6230745]

4. Olivares Jimenez JL, Guerrero Jurado JC, Bermudez Rodriguez FJ, Serrano Laborda D. Keratoconus: age of onset and natural history. Optom Vis Sci. 1997; 74:147-151. [PubMed: 9159804]

5. Klintworth GK, Damms T. Corneal dystrophies and keratoconus. Curr Opin Ophthalmol. 1995; 6:44-56. [PubMed: 10150882]

6. Kang PC, Klintworth GK, Kim T, Carlson AN, Adelman R, et al. Trends in the indications for penetrating keratoplasty, 1980-2001. Cornea. 2005; 24:801-803. [PubMed: 16160495]

7. Hofstetter HW. A keratoscopic survey of 13,395 eyes. Am J Optom Arch Am Acad Optom. 1959; 36:3-11. [PubMed: 13617405]

8. Kennedy RH, Bourne WM, Dyer JA. A 48-year clinical and epidemiologic study of keratoconus. Am J Ophthalmol. 1986; 101:267-273. [PubMed: 3513592]

9. Kok YO, Tan GF, Loon SC. Review: Keratoconus in Asia. Cornea. 2012; 31:581-593. [PubMed: 22314815]

10. Nielsen K, Hjortdal J, Aagaard Nohr E, Ehlers N. Incidence and prevalence of keratoconus in Denmark. Acta Ophthalmol Scand. 2007; 85:890-892. [PubMed: 17645421]

11. Millodot M, Shneor E, Albou S, Atlani E, Gordon-Shaag A. Prevalence and associated factors of keratoconus in Jerusalem: a cross-sectional study. Ophthalmic Epidemiol. 2011; 18:91-97. [PubMed: 21401417]

12. Jonas JB, Nangia V, Matin A, Kulkarni M, Bhojwani K. Prevalence and associations of keratoconus in rural maharashtra in central India: the central India eye and medical study. Am J Ophthalmol. 2009; 148:760-765. [PubMed: 19674732]

13. Assiri AA, Yousuf BI, Quantock AJ, Murphy PJ. Incidence and severity of keratoconus in Asir province, Saudi Arabia. Br J Ophthalmol. 2005; 89:1403-1406. [PubMed: 16234439]

14. Karimian F, Aramesh S, Rabei HM, Javadi MA, Rafati N. Topographic evaluation of relatives of patients with keratoconus. Cornea. 2008; 27:874-878. [PubMed: 18724146]

15. Aknin C, Allart JF, Rouland JF. Unilateral keratoconus and mirror image in a pair of monozygotic twins]. J Fr Ophtalmol. 2007; 30:899-902. [PubMed: 18046272]

16. Weed KH, MacEwen CJ, McGhee CN. The variable expression of keratoconus within monozygotic twins: dundee University Scottish Keratoconus Study (DUSKS). Cont Lens Anterior Eye. 2006; 29:123-126. [PubMed: 16677846]

17. Owens H, Gamble G. A profile of keratoconus in New Zealand. Cornea. 2003; 22:122-125. [PubMed: 12605045] 
18. Schmitt-Bernard C, Schneider CD, Blanc D, Arnaud B. Keratographic analysis of a family with keratoconus in identical twins. J Cataract Refract Surg. 2000; 26:1830-1832. [PubMed: 11134887]

19. Parker J, Ko WW, Pavlopoulos G, Wolfe PJ, Rabinowitz YS, et al. Videokeratography of keratoconus in monozygotic twins. J Refract Surg. 1996; 12:180-183. [PubMed: 8963810]

20. Hughes AE, Dash DP, Jackson AJ, Frazer DG, Silvestri G. Familial keratoconus with cataract: linkage to the long arm of chromosome 15 and exclusion of candidate genes. Invest Ophthalmol Vis Sci. 2003; 44:5063-5066. [PubMed: 14638698]

21. Rabinowitz YS. The genetics of keratoconus. Ophthalmol Clin North Am. 2003; 16:607-620. [PubMed: 14741001]

22. Stabuc-Silih M, Strazisar M, Ravnik-Glavac M, Hawlina M, Glavac D. Genetics and clinical characteristics of keratoconus. Acta Dermatovenerol Alp Panonica Adriat. 2010; 19:3-10. [PubMed: 20664914]

23. Kirby D, Jackson AP, Karbani G, Crow YJ. Mental retardation, keratoconus, febrile seizures and sinoatrial block: a previously undescribed autosomal recessive disorder. Clin Genet. 2005; 67:448-449. [PubMed: 15811017]

24. Abu-Amero KK, Kalantan H, Al-Muammar AM. Analysis of the VSX1 gene in keratoconus patients from Saudi Arabia. Mol Vis. 2011; 17:667-672. [PubMed: 21403853]

25. Liu Y, Allingham RR. Molecular genetics in glaucoma. Exp Eye Res. 2011; 93:331-339. [PubMed: 21871452]

26. Nowak DM, Gajecka M. The genetics of keratoconus. Middle East Afr J Ophthalmol. 2011; 18:26. [PubMed: 21572727]

27. Bisceglia L, De Bonis P, Pizzicoli C, Fischetti L, Laborante A, et al. Linkage analysis in keratoconus: replication of locus 5q21.2 and identification of other suggestive Loci. Invest Ophthalmol Vis Sci. 2009; 50:1081-1086. [PubMed: 18978346]

28. Tang YG, Rabinowitz YS, Taylor KD, Li X, Hu M, et al. Genomewide linkage scan in a multigeneration Caucasian pedigree identifies a novel locus for keratoconus on chromosome 5q14.3-q21.1. Genet Med. 2005; 7:397-405. [PubMed: 16024971]

29. Li X, Rabinowitz YS, Tang YG, Picornell Y, Taylor KD, et al. Invest Ophthalmol Vis Sci. 2006; 47:3791-3795. [PubMed: 16936089]

30. Tyynismaa H, Sistonen P, Tuupanen S, Tervo T, Dammert A, et al. A locus for autosomal dominant keratoconus: linkage to 16q22.3-q23.1 in Finnish families. Invest Ophthalmol Vis Sci. 2002; 43:3160-3164. [PubMed: 12356819]

31. Hayashi T, Huang J, Deeb SS. RINX(VSX1), a novel homeobox gene expressed in the inner nuclear layer of the adult retina. Genomics. 2000; 67:128-139. [PubMed: 10903837]

32. Semina EV, Mintz-Hittner HA, Murray JC. Isolation and characterization of a novel human pairedlike homeodomain-containing transcription factor gene, VSX1, expressed in ocular tissues. Genomics. 2000; 63:289-293. [PubMed: 10673340]

33. Heon E, Mathers WD, Alward WL, Weisenthal RW, Sunden SL, et al. Linkage of posterior polymorphous corneal dystrophy to 20q11. Hum Mol Genet. 1995; 4:485-488. [PubMed: 7795607]

34. Driver PJ, Reed JW, Davis RM. Familial cases of keratoconus associated with posterior polymorphous dystrophy. Am J Ophthalmol. 1994; 118:256-257. [PubMed: 8053477]

35. Blair SD, Seabrooks D, Shields WJ, Pillai S, Cavanagh HD. Bilateral progressive essential iris atrophy and keratoconus with coincident features of posterior polymorphous dystrophy: a case report and proposed pathogenesis. Cornea. 1992; 11:255-261. [PubMed: 1587135]

36. Mazzotta C, Baiocchi S, Caporossi O, Buccoliero D, Casprini F, et al. Confocal microscopy identification of keratoconus associated with posterior polymorphous corneal dystrophy. J Cataract Refract Surg. 2008; 34:318-321. [PubMed: 18242460]

37. Bechara SJ, Grossniklaus HE, Waring GO 3rd, Wells JA 3rd. Keratoconus associated with posterior polymorphous dystrophy. Am J Ophthalmol. 1991; 112:729-731. [PubMed: 1957913]

38. Gasset AR, Zimmerman TJ. Posterior polymorphous dystrophy associated with keratoconus. Am J Ophthalmol. 1974; 78:535-537. [PubMed: 4547273]

39. Weissman BA, Ehrlich M, Levenson JE, Pettit TH. Four cases of keratoconus and posterior polymorphous corneal dystrophy. Optom Vis Sci. 1989; 66:243-246. [PubMed: 2786175] 
40. Heon E, Greenberg A, Kopp KK, Rootman D, Vincent AL, et al. VSX1: a gene for posterior polymorphous dystrophy and keratoconus. Hum Mol Genet. 2002; 11:1029-1036. [PubMed: 11978762]

41. Chow RL, Volgyi B, Szilard RK, Ng D, McKerlie C, et al. Control of late off-center cone bipolar cell differentiation and visual signaling by the homeobox gene Vsx1. Proc Natl Acad Sci U S A. 2004; 101:1754-1759. [PubMed: 14745032]

42. Ohtoshi A, Wang SW, Maeda H, Saszik SM, Frishman LJ, et al. Regulation of retinal cone bipolar cell differentiation and photopic vision by the CVC homeobox gene Vsx1. Curr Biol. 2004; 14:530-536. [PubMed: 15043821]

43. Watson TC, how RL. Absence of Vsx1 expression in the normal and damaged mouse cornea. Mol Vis. 2011; 17:737-744. [PubMed: 21437200]

44. Mok JW, Baek SJ, Joo CK. VSX1 gene variants are associated with keratoconus in unrelated Korean patients. J Hum Genet. 2008; 53:842-849. [PubMed: 18626569]

45. Mintz-Hittner HA, Semina EV, Frishman LJ, Prager TC, Murray JC. VSX1 (RINX) mutation with craniofacial anomalies, empty sella, corneal endothelial changes, and abnormal retinal and auditory bipolar cells. Ophthalmology. 2004; 111:828-836. [PubMed: 15051220]

46. Bisceglia L, Ciaschetti M, De Bonis P, Campo PA, Pizzicoli C, et al. VSX1 mutational analysis in a series of Italian patients affected by keratoconus: detection of a novel mutation. Invest Ophthalmol Vis Sci. 2005; 46:39-45. [PubMed: 15623752]

47. Eran P, Almogit A, David Z, Wolf HR, Hana G, et al. The D144E substitution in the VSX1 gene: a non-pathogenic variant or a disease causing mutation? Ophthalmic Genet. 2008; 29:53-59. [PubMed: 18484309]

48. Paliwal P, Singh A, Tandon R, Titiyal JS, Sharma A. A novel VSX1 mutation identified in an individual with keratoconus in India. Mol Vis. 2009; 15:2475-2479. [PubMed: 19956409]

49. Dash DP, George S, O'Prey D, Burns D, Nabili S, et al. Mutational screening of VSX1 in keratoconus patients from the European population. Eye (Lond). 2010; 24:1085-1092. [PubMed: 19763142]

50. De Bonis P, Laborante A, Pizzicoli C, Stallone R, Barbano R, et al. Mutational screening of VSX1, SPARC, SOD1, LOX, and TIMP3 in keratoconus. Mol Vis. 2011; 17:2482-2494. [PubMed: 21976959]

51. Paliwal P, Tandon R, Dube D, Kaur P, Sharma A. Familial segregation of a VSX1 mutation adds a new dimension to its role in the causation of keratoconus. Mol Vis. 2011; 17:481-485. [PubMed: 21365019]

52. Saee-Rad S, Hashemi H, Miraftab M, Noori-Daloii MR, Chaleshtori MH, et al. Mutation analysis of VSX1 and SOD1 in Iranian patients with keratoconus. Mol Vis. 2011; 17:3128-3136. [PubMed: 22171159]

53. Aldave AJ, Yellore VS, Salem AK, Yoo GL, Rayner SA, et al. No VSX1 gene mutations associated with keratoconus. Invest Ophthalmol Vis Sci. 2006; 47:2820-2822. [PubMed: 16799019]

54. Liskova P, Ebenezer ND, Hysi PG, Gwilliam R, El-Ashry MF, et al. Molecular analysis of the VSX1 gene in familial keratoconus. Mol Vis. 2007; 13:1887-1891. [PubMed: 17960127]

55. Hosseini SM, Herd S, Vincent AL, Heon E. Genetic analysis of chromosome 20-related posterior polymorphous corneal dystrophy: genetic heterogeneity and exclusion of three candidate genes. Mol Vis. 2008; 14:71-80. [PubMed: 18253095]

56. Tang YG, Picornell Y, Su X, Li X, Yang H, et al. Three VSX1 gene mutations, L159M, R166W, and H244R, are not associated with keratoconus. Cornea. 2008; 27:189-192. [PubMed: 18216574]

57. Gajecka M, Radhakrishna U, Winters D, Nath SK, Rydzanicz M, et al. Localization of a gene for keratoconus to a 5.6-Mb interval on 13q32. Invest Ophthalmol Vis Sci. 2009; 50:1531-1539. [PubMed: 19011015]

58. Lam HY, Wiggs JL, Jurkunas UV. Unusual presentation of presumed posterior polymorphous dystrophy associated with iris heterochromia, band keratopathy, and keratoconus. Cornea. 2010; 29:1180-1185. [PubMed: 20567203]

59. Stabuc-Silih M, Strazisar M, Hawlina M, Glavac D. Absence of pathogenic mutations in VSX1 and SOD1 genes in patients with keratoconus. Cornea. 2010; 29:172-176. [PubMed: 20023586] 
60. Tanwar M, Kumar M, Nayak B, Pathak D, Sharma N, et al. VSX1 gene analysis in keratoconus. Mol Vis. 2010; 16:2395-2401. [PubMed: 21139977]

61. Aldave AJ. VSX1 mutation and corneal dystrophies. Ophthalmology. 2005; 112:171-172.

62. Hughes AE, Bradley DT, Campbell M, Lechner J, Dash DP, et al. Mutation altering the miR-184 seed region causes familial keratoconus with cataract. Am J Hum Genet. 2011; 89:628-633. [PubMed: 21996275]

63. Dash DP, Silvestri G, Hughes AE. Fine mapping of the keratoconus with cataract locus on chromosome 15q and candidate gene analysis. Mol Vis. 2006; 12:499-505. [PubMed: 16735990]

64. Karali M, Peluso I, Gennarino VA, Bilio M, Verde R, et al. miRNeye: a microRNA expression atlas of the mouse eye. BMC Genomics. 2010; 11:715. [PubMed: 21171988]

65. Ryan DG, Oliveira-Fernandes M, Lavker RM. MicroRNAs of the mammalian eye display distinct and overlapping tissue specificity. Mol Vis. 2006; 12:1175-1184. [PubMed: 17102797]

66. Kwofie MA, Skowronski J. Specific recognition of Rac2 and Cdc42 by DOCK 2 and DOCK9 guanine nucleotide exchange factors. J Biol Chem. 2008; 283:3088-3096. [PubMed: 18056264]

67. Czugala M, Karolak JA, Nowak DM, Polakowski P, Pitarque J, et al. Novel mutation and three other sequence variants segregating with phenotype at keratoconus $13 \mathrm{q} 32$ susceptibility locus. Eur J Hum Genet:. 2012; 20:389-397. [PubMed: 22045297]

68. Ramensky V, Bork P, Sunyaev S. Human non-synonymous SNPs: server and survey. Nucleic Acids Res. 2002; 30:3894-3900. [PubMed: 12202775]

69. Ng PC, Henikoff S. Predicting deleterious amino acid substitutions. Genome Res. 2001; 11:863874. [PubMed: 11337480]

70. Udar N, Atilano SR, Brown DJ, Holguin B, Small K, et al. SOD1: a candidate gene for keratoconus. Invest Ophthalmol Vis Sci. 2006; 47:3345-3351. [PubMed: 16877401]

71. Noor R, Mittal S, Iqbal J. Superoxide dismutase--applications and relevance to human diseases. Med Sci Monit. 2002; 8:210-215.

72. Rosen DR, Siddique T, Patterson D, Figlewicz DA, Sapp P, et al. Mutations in Cu/Zn superoxide dismutase gene are associated with familial amyotrophic lateral sclerosis. Nature. 1993; 362:59_ 62. [PubMed: 8446170]

73. Arnal E, Peris-Martinez C, Menezo JL, Johnsen-Soriano S, Romero FJ. Oxidative stress in keratoconus? Invest Ophthalmol Vis Sci. 2011; 52:8592-8597. [PubMed: 21969298]

74. Pathak D, Nayak B, Singh M, Sharma N, Tandon R, et al. Mitochondrial complex 1 gene analysis in keratoconus. Mol Vis. 2011; 17:1514-1525. [PubMed: 21691575]

75. Atilano SR, Coskun P, Chwa M, Jordan N, Reddy V, et al. Accumulation of mitochondrial DNA damage in keratoconus corneas. Invest Ophthalmol Vis Sci. 2005; 46:1256-1263. [PubMed: 15790887]

76. Buddi R, Lin B, Atilano SR, Zorapapel NC, Kenney MC, et al. Evidence of oxidative stress in human corneal diseases. J Histochem Cytochem. 2002; 50:341-351. [PubMed: 11850437]

77. Udar N, Atilano SR, Small K, Nesburn AB, Kenney MC. SOD1 haplotypes in familial keratoconus. Cornea. 2009; 28:902-907. [PubMed: 19654524]

78. Manolio TA. Genomewide association studies and assessment of the risk of disease. N Engl J Med. 2010; 363:166-176. [PubMed: 20647212]

79. Baratz KH, Tosakulwong N, Ryu E, Brown WL, Branham K, et al. E2-2 protein and Fuchs's corneal dystrophy. N Engl J Med. 2010; 363:1016-1024. [PubMed: 20825314]

80. Lively GD, Koehn D, Hedberg-Buenz A, Wang K, Anderson MG. Quantitative trait loci associated with murine central corneal thickness. Physiol Genomics. 2010; 42:281-286. [PubMed: 20423963]

81. Lu Y, Dimasi DP, Hysi PG, Hewitt AW, Burdon KP, et al. Common genetic variants near the Brittle Cornea Syndrome locus ZNF469 influence the blinding disease risk factor central corneal thickness. PLoS Genet. 2010; 6:1000947.

82. Vitart V, Bencic G, Hayward C, Herman JS, Huffman J, et al. New loci associated with central cornea thickness include COL5A1, AKAP13 and AVGR8. Hum Mol Genet. 2010 
83. Vithana EN, Aung T, Khor CC, Cornes BK, Tay WT, et al. Collagen-related genes influence the glaucoma risk factor, central corneal thickness. Hum Mol Genet. 2011; 20:649-658. [PubMed: 21098505]

84. Cornes BK, Khor CC, Nongpiur ME, Xu L, Tay WT, et al. Identification of four novel variants that influence central corneal thickness in multi-ethnic Asian populations. Hum Mol Genet. 2012; 21:437-445. [PubMed: 21984434]

85. Li X, Bykhovskaya Y, Haritunians T, Siscovick D, Aldave A, et al. A genome-wide association study identifies a potential novel gene locus for keratoconus, one of the commonest causes for corneal transplantation in developed countries. Hum Mol Genet. 2012; 21:421-429. [PubMed: 21979947]

86. Morris-Rosendahl DJ, Segel R, Born AP, Conrad C, Loeys B, et al. New RAB3GAP1 mutations in patients with Warburg Micro Syndrome from different ethnic backgrounds and a possible founder effect in the Danish. Eur J Hum Genet. 2010; 18:1100-1106. [PubMed: 20512159]

87. Aligianis IA, Johnson CA, Gissen P, Chen D, Hampshire D, et al. Mutations of the catalytic subunit of RAB3GAP cause Warburg Micro syndrome. Nat Genet. 2005; 37:221-223. [PubMed: 15696165]

88. Burdon KP, Macgregor S, Bykhovskaya Y, Javadiyan S, Li X, et al. Association of polymorphisms in the hepatocyte growth factor gene promoter with keratoconus. Invest Ophthalmol Vis Sci. 2011; 52:8514-8519. [PubMed: 22003120]

89. Veerappan S, Pertile KK, Islam AF, Schache M, Chen CY, et al. Role of the hepatocyte growth factor gene in refractive error. Ophthalmology. 2010; 117:239-245. e231-232. [PubMed: 20005573]

90. Yanovitch T, Li YJ, Metlapally R, Abbott D, Viet KN, et al. Hepatocyte growth factor and myopia: genetic association analyses in a Caucasian population. Mol Vis. 2009; 15:1028-1035. [PubMed: 19471602]

91. Han W, Yap MK, Wang J, Yip SP. Family-based association analysis of hepatocyte growth factor (HGF) gene polymorphisms in high myopia. Invest Ophthalmol Vis Sci. 2006; 47:2291-2299. [PubMed: 16723436]

92. Liu Y, Gibson J, Wheeler J, Kwee LC, Santiago-Turla CM, et al. GALC deletions increase the risk of primary open-angle glaucoma: the role of Mendelian variants in complex disease. PLoS One. 2011; 6:e27134. [PubMed: 22073273]

93. Zhang F, Gu W, Hurles ME, Lupski JR. Copy number variation in human health, disease, and evolution. Annu Rev Genomics Hum Genet. 2009; 10:451-481. [PubMed: 19715442]

94. Abu-Amero KK, Hellani AM, Al Mansouri SM, Kalantan H, Al-Muammar AM. High-resolution analysis of DNA copy number alterations in patients with isolated sporadic keratoconus. Mol Vis. 2011; 17:822-826. [PubMed: 21528002]

95. Rosenfeld JA, Drautz JM, Clericuzio CL, Cushing T, Raskin S, et al. Deletions and duplications of developmental pathway genes in 5q31 contribute to abnormal phenotypes. Am J Med Genet A. 2011; 155A:1906-1916. [PubMed: 21744490]

96. Klintworth GK. Advances in the molecular genetics of corneal dystrophies. Am J Ophthalmol. 1999; 128:747-754. [PubMed: 10612512]

97. Shapiro MB, France TD. The ocular features of Down's syndrome. Am J Ophthalmol. 1985; 99:659-663. [PubMed: 3160242]

98. Elder MJ. Leber congenital amaurosis and its association with keratoconus and keratoglobus. J Pediatr Ophthalmol Strabismus. 1994; 31:38-40. [PubMed: 8195961]

99. McMahon TT, Kim LS, Fishman GA, Stone EM, Zhao XC, et al. CRB1 gene mutations are associated with keratoconus in patients with leber congenital amaurosis. Invest Ophthalmol Vis Sci. 2009; 50:3185-3187. [PubMed: 19407021]

100. Dharmaraj S, Leroy BP, Sohocki MM, Koenekoop RK, Perrault I, et al. The phenotype of Leber congenital amaurosis in patients with AIPL1 mutations. Arch Ophthalmol. 2004; 122:1029_ 1037. [PubMed: 15249368]

101. McKibbin M, Ali M, Mohamed MD, Booth AP, Bishop F, et al. Genotype-phenotype correlation for leber congenital amaurosis in Northern Pakistan. Arch Ophthalmol. 2010; 128:107-113. [PubMed: 20065226] 
102. Damji KF, Sohocki MM, Khan R, Gupta SK, Rahim M, et al. Leber's congenital amaurosis with anterior keratoconus in Pakistani families is caused by the Trp278X mutation in the AIPL1 gene on 17p. Canadian journal of ophthalmology. Can J Ophthalmol. 2001; 36:252-259. [PubMed: 11548141]

103. Stoiber J, Muss WH, Ruckhofer J, Thaller-Antlanger H, Alzner E, et al. Recurrent keratoconus in a patient with Leber congenital amaurosis. Cornea. 2000; 19:395-398. [PubMed: 10832707]

104. Balasubramanian SA, Pye DC, Willcox MD. Are proteinases the reason for keratoconus? Curr Eye Res. 2010; 35:185-191. [PubMed: 20373876]

105. Beckh U, Schonherr U, Naumann GO. Autosomal dominant keratoconus as the chief ocular symptom in Lobstein osteogenesis imperfecta tarda. Klin Monbl fur Augenheilkd. 1995; 206:268-272.

106. Wajntal A, Koiffmann CP, Mendonca BB, Epps-Quaglia D, Sotto MN, et al. GAPO syndrome (McKusick 23074)--a connective tissue disorder: report on two affected sibs and on the pathologic findings in the older. Am J Med Genet. 1990; 37:213-223. [PubMed: 2248288]

107. Robertson I. Keratoconus and the Ehlers-Danlos syndrome: a new aspect of keratoconus. Med J Aust. 1975; 1:571-573. [PubMed: 1143149]

108. Street DA, Vinokur ET, Waring GO 3rd, Pollak SJ, Clements SD, et al. Lack of association between keratoconus, mitral valve prolapse, and joint hypermobility. Ophthalmology. 1991; 98:170-176. [PubMed: 2008274]

109. Thomas JK, Guel DA, Thomas TS, Cavanagh HD. The role of atopy in corneal graft survival in keratoconus. Cornea. 2011; 30:1088-1097. [PubMed: 21795976]

110. Yildiz EH, Erdurmus M, Hammersmith KM, Rapuano CJ, Laibson PR, et al. Comparative study of graft rejection in keratoconus patients with and without self-reported atopy. Cornea. 2009; 28:846-850. [PubMed: 19654535]

111. McMonnies CW, Boneham GC. Keratoconus, allergy, itch, eye-rubbing and hand-dominance. Clin Exp Optom. 2003; 86:376-384. [PubMed: 14632614]

112. Jacq PL, Sale Y, Cochener B, Lozach P, Colin J. Keratoconus, changes in corneal topography and allergy. Study of 3 groups of patients. J Fr Ophtalmoll. 1997; 20:97-102.

113. Harrison RJ, Klouda PT, Easty DL, Manku M, Charles J, et al. Association between keratoconus and atopy. Br J Ophthalmol. 1989; 73:816-822. [PubMed: 2818991]

114. Rahi A, Davies P, Ruben M, Lobascher D, Menon J. Keratoconus and coexisting atopic disease. Br J Ophthalmol. 1977; 61:761-764. [PubMed: 603783]

115. Kaya V, Karakaya M, Utine CA, Albayrak S, Oge OF, et al. Evaluation of the corneal topographic characteristics of keratoconus with orbscan II in patients with and without atopy. Cornea. 2007; 26:945-948. [PubMed: 17721293]

116. Bawazeer AM, Hodge WG, Lorimer B. Atopy and keratoconus: a multivariate analysis. Br J Ophthalmol. 2000; 84:834-836. [PubMed: 10906086]

117. Teer JK, Mullikin JC. Exome sequencing: the sweet spot before whole genomes. Hum Mol Genet. 2010; 19:R145-151. [PubMed: 20705737]

118. Bick D, Dimmock D. Whole exome and whole genome sequencing. Curr Opin Pediatr. 2011; 23:594-600. [PubMed: 21881504]

119. Bamshad MJ, Ng SB, Bigham AW, Tabor HK, Emond MJ, et al. Exome sequencing as a tool for Mendelian disease gene discovery. Nat Rev Genet. 2011; 12:745-755. [PubMed: 21946919]

120. Burdon KP, Coster DJ, Charlesworth JC, Mills RA, Laurie KJ, et al. Apparent autosomal dominant keratoconus in a large Australian pedigree accounted for by digenic inheritance of two novel loci. Hum Genet. 2008; 124:379-386. [PubMed: 18795334]

121. Hutchings H, Ginisty H, Le Gallo M, Levy D, Stoesser F, et al. Identification of a new locus for isolated familial keratoconus at 2p24. J Med Genet. 2005; 42:88-94. [PubMed: 15635082]

122. Brancati F, Valente EM, Sarkozy A, Feher J, Castori M, et al. A locus for autosomal dominant keratoconus maps to human chromosome 3p14-q13. J Med Genet. 2004; 41:188-192. [PubMed: 14985379]

123. Liskova P, Hysi PG, Waseem N, Ebenezer ND, Bhattacharya SS, et al. Evidence for keratoconus susceptibility locus on chromosome 14: a genome-wide linkage screen using single-nucleotide polymorphism markers. Arch Ophthalmol. 2010; 128:1191-1195. [PubMed: 20837804] 
124. Hameed A, Khaliq S, Ismail M, Anwar K, Ebenezer ND, et al. A novel locus for Leber congenital amaurosis (LCA4) with anterior keratoconus mapping to chromosome 17p13. Invest Ophthalmol Vis Sci. 2000; 41:629-633. [PubMed: 10711674]

125. Fullerton J, Paprocki P, Foote S, Mackey DA, Williamson R, et al. Identity-by-descent approach to gene localisation in eight individuals affected by keratoconus from north-west Tasmania, Australia. Hum Genet. 2002; 110:462. [PubMed: 12073017] 


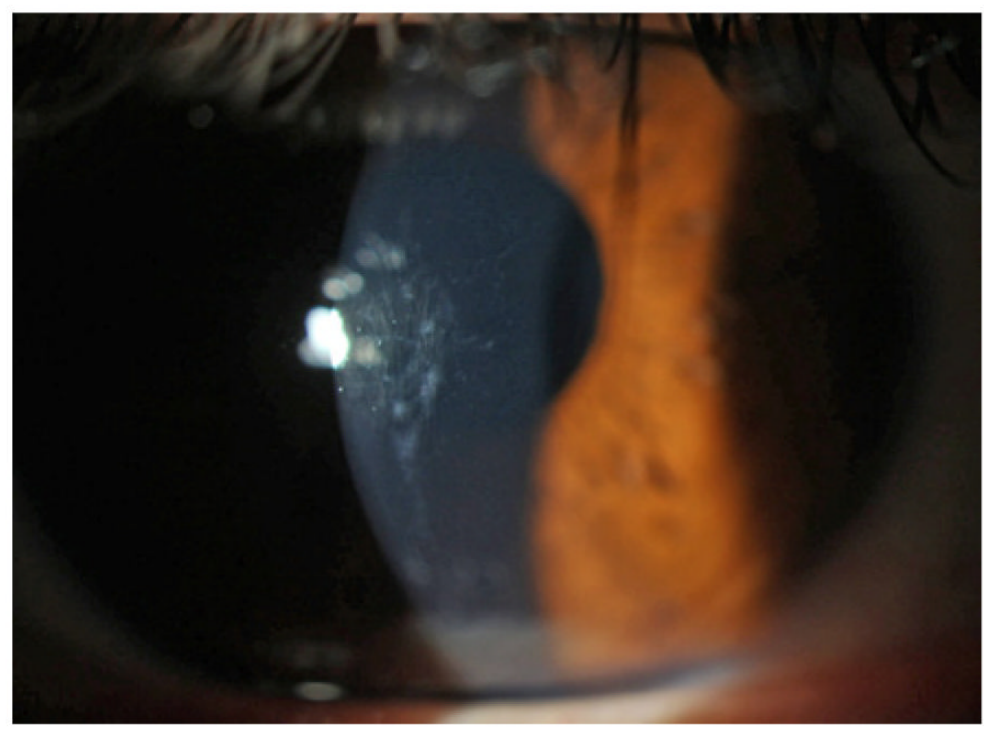

Figure 1.

Vogt's Striae Sign. Vertical lines in Descemet's membrane are observed. 


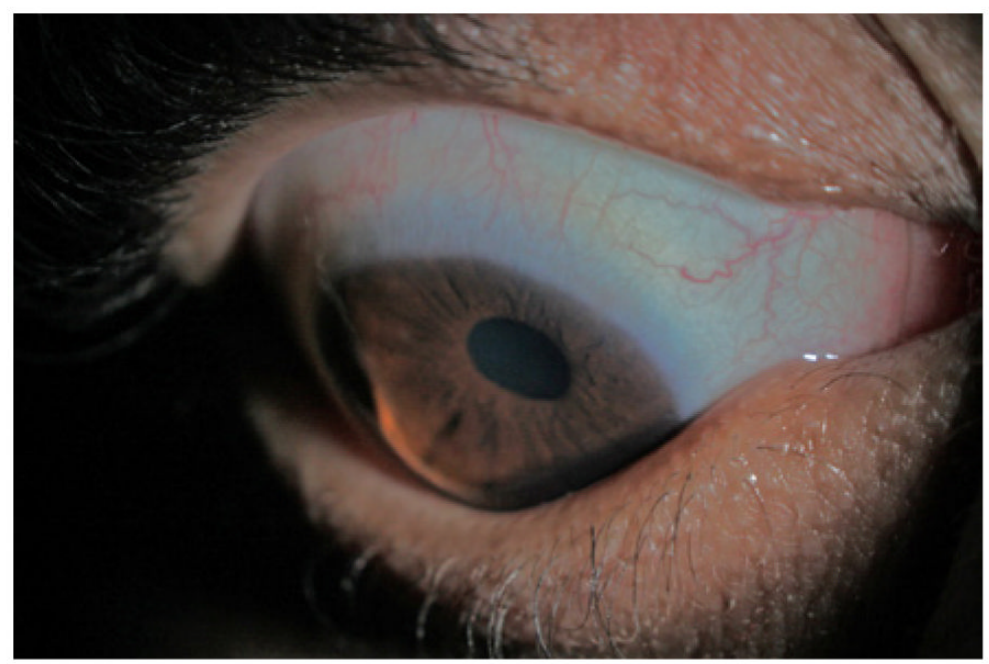

Figure 2.

Munson's sign.Cone is noted on the lower eyelid on the downgaze. 


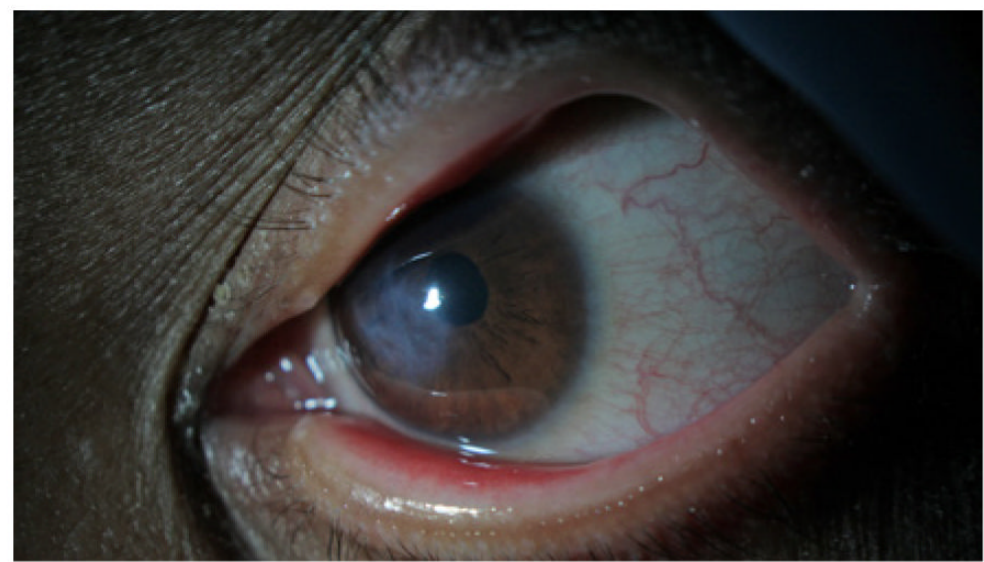

Figure 3.

Corneal Hydrops. Breaks in Descemet's membrane in severe keratoconus cause acute stromal edema and scarring. 


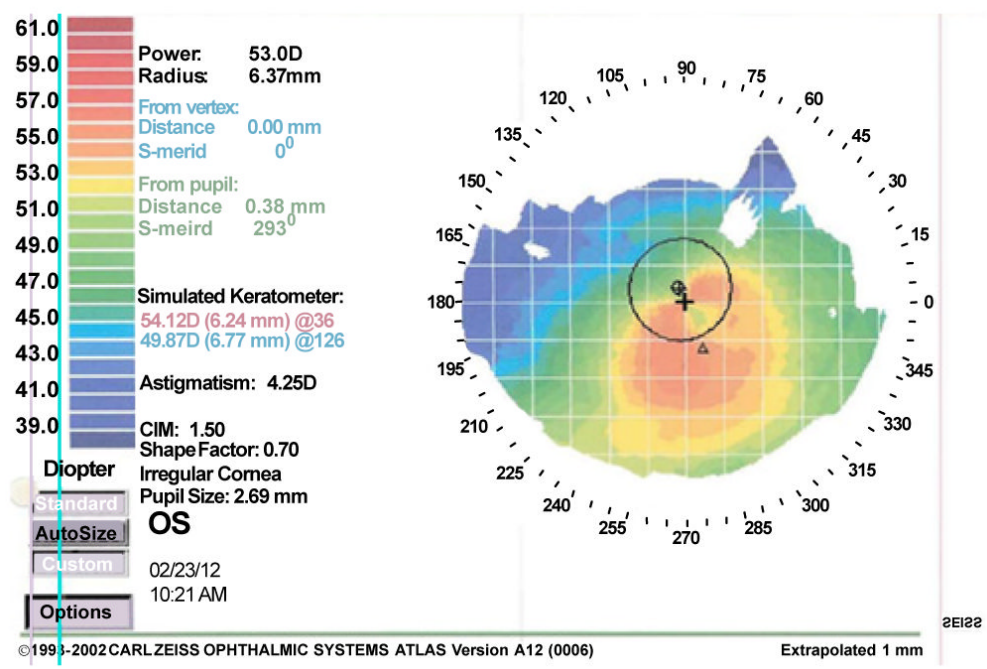

Figure 4.

Corneal topography map in advanced keratoconus of left eye (OS for oculus sinister). Blue color indicates areas of fattest curvature. Red indicates the steepest curvature, which is the area with irregular protruding cone, a common feature of keratoconus. 
Table 1

List of the identified genomic loci through linkage studies.

\begin{tabular}{|c|c|c|c|}
\hline Location & Mode of Inheritance & Population & Reference \\
\hline $1 \mathrm{p} 36.23-36.21$ & Autosomal-dominant & Australian & {$[120]$} \\
\hline $2 \mathrm{p} 24$ & & $\begin{array}{c}\text { European, Arabic, Carib- } \\
\text { bean African }\end{array}$ & {$[121]$} \\
\hline $3 \mathrm{p} 14-\mathrm{q} 13$ & Autosomal-dominant & Italian & {$[122]$} \\
\hline $5 \mathrm{q} 14.3-\mathrm{q} .21 .1$ & Autosomal-dominant & $\begin{array}{c}\text { Caucasian, Sourthern } \\
\text { Italian }\end{array}$ & {$[27,28]$} \\
\hline $5 \mathrm{q} 23.2$ & & Caucasian, Hispanic & {$[29]$} \\
\hline $5 \mathrm{q} 32-\mathrm{q} 33$ & & Southern Italian & {$[27]$} \\
\hline $8 \mathrm{q} 13.1-\mathrm{q} 21.11$ & Autosomal-dominant & Australian & {$[120]$} \\
\hline $9 \mathrm{q} 34$ & & Caucasian, Hispanic & {$[29]$} \\
\hline $13 \mathrm{q} 32$ & Autosomal-dominant & Ecuadorian & {$[57]$} \\
\hline $14 \mathrm{q} 11.2$ & & Southern Italian & {$[27]$} \\
\hline $14 \mathrm{q} 11.2$ & & Caucasian, Hispanic & {$[29]$} \\
\hline $14 \mathrm{q} 24.3$ & & Multi-ethnic & {$[123]$} \\
\hline $15 \mathrm{q} 2.32$ & & Southern Italian & {$[27]$} \\
\hline $15 \mathrm{q} 22.33-24.2$ & Autosomal-dominant & Northern Irish & {$[20]$} \\
\hline $16 \mathrm{q} 22.3-\mathrm{q} 23.1$ & Autosomal-dominant & Finnish & {$[30]$} \\
\hline $17 \mathrm{p} 13$ & Autosomal-recessive & Pakistani & {$[124]$} \\
\hline $20 \mathrm{q} 12$ & Autosomal-dominant & Australian, Tasmania & {$[125]$} \\
\hline
\end{tabular}


Table 2

List of sequence variants identified in the VSX1 gene.

\begin{tabular}{|c|c|c|c|c|c|}
\hline cDNA change & Protein & dbSNP135 & Accession\# & Pathogenic & References \\
\hline c. $50 \mathrm{~T}>\mathrm{C}$ & L17P & rs74315436 & NM_014588 & Polymorphic & {$[46,49,50]$} \\
\hline c. $315 \mathrm{C}>\mathrm{A}$ & D105E & rs6115023 & NM_014588 & Polymorphic & [54] \\
\hline c. $391 \mathrm{C}>\mathrm{A}$ & $\mathrm{R} 131 \mathrm{~S}$ & rs6050307 & NM_014588 & Polymorphic & {$[53,54]$} \\
\hline c. $432 \mathrm{C}>\mathrm{G}$ & $\mathrm{D} 144 \mathrm{E}$ & rs140122268 & NM_014588 & Polymorphic & {$[40,46,47,49,50,53,54]$} \\
\hline c. $452 \mathrm{~A}>\mathrm{G}$ & N151S & - & NM_014588 & Pathogenic & [44] \\
\hline c. $475 \mathrm{~T}>\mathrm{A}$ & L159M & rs74315434 & NM_014588 & Polymorphic & {$[40,56]$} \\
\hline c. $479 \mathrm{G}>\mathrm{A}$ & G160D & rs74315433 & NM_014588 & Polymorphic & {$[40,46,49,50]$} \\
\hline c. $479 \mathrm{G}>\mathrm{T}$ & G160V & rs74315433 & NM_014588 & Polymorphic & [44] \\
\hline c. $496 \mathrm{C}>\mathrm{T}$ & R166W & - & NM_014588 & Pathogenic & {$[40,52]$} \\
\hline c. $525 \mathrm{G}>\mathrm{C}$ & Q175H & - & NM_014588 & Pathogenic & {$[48,51]$} \\
\hline c. $650 \mathrm{G}>\mathrm{A}$ & $\mathrm{R} 217 \mathrm{H}$ & rs6138482 & NM_199425 & Polymorphic & {$[49,54,59]$} \\
\hline c. $715 \mathrm{G}>\mathrm{C}$ & G239R & - & NM_014588 & Pathogenic & [50] \\
\hline c. $731 \mathrm{~A}>\mathrm{G}$ & $\mathrm{H} 244 \mathrm{R}$ & rs148957473 & NM_014588 & Polymorphic & {$[40,52,56]$} \\
\hline c. $740 \mathrm{C}>\mathrm{G}$ & $\mathrm{P} 247 \mathrm{R}$ & - & NM_014588 & Pathogenic & {$[40,46,50]$} \\
\hline c. $766 \mathrm{G}>\mathrm{T}$ & A256S & rs74315435 & NM_014588 & Polymorphic & [45] \\
\hline
\end{tabular}

